\title{
Effects of Work Life Balance on Employee Loyalty in Private Commercial Banks of Bangladesh
}

\author{
Md. Awal Al Kabir \\ Associate professor, \\ Dept. of Management Studies, \\ Faculty of Business Studies \\ Jahangirnar University, \\ Savar, Dhaka, Bangladesh. \\ Murshida Rahman \\ Lecturer, \\ Army Institute of Business Administration, \\ Savar Cantonment, Dhaka, Bangladesh.
}

\begin{abstract}
Maintaining employees' personal life and work life- which is referred as Work Life Balance- is a recent concept of contemporary Human Resource Management. Banking sector provides one of the busiest working environments in Bangladesh. To achieve its' business objectives banking sector needs to develop the professional lives of the employees along with their family lives. The study examines employee loyalty's relationship with work life balance opportunities in private commercial banking sector of Bangladesh. The specific objectives of the research are- to examine to what extend the private commercial banks are giving opportunities to their employees to have proper work life balance, to explore the perceptions of the employees to current work schedule and the factors which are dependent on their loyalty to the organization,. The research adopts a research design where the population size is thirty nine (39) and the sample size is ten (10) private commercial banks. At least hundred (100) structured questionnaires are being filled completely by the employees.Various factors are identified that are directly related to Work Life Balance and employee loyalty such as working hours, leave policies, holidays/ picnics, health programs, work pressure, work distribution, job satisfaction, etc. The findings are based on the employees' present situation of work life balance in connection with employee loyalty. Recommendations are given on the basis of the areas which need to be focused more and on the basis of the top managements' responsibilities to make their employees loyal through providing work life balance.If the implementation of the suggested recommendations can be ensured, the objectives of the study will be achieved. Moreover, the study can also help the managers of various organizations to understand how Work Life balance policies can influence proper job satisfaction of employees.
\end{abstract}

Key words: Work Life Balance, Employee Loyalty, Job satisfaction, Private Commercial Banking Industry

DOI: $10.7176 / \mathrm{JESD} / 10-14-18$

Publication date:July $31^{\text {st }} 2019$

\section{Introduction}

In this era of globalization, organizations are becoming more formal and output oriented. As they have to compete with other organizations. Banking sector of Bangladesh especially the Private Commercial Banking sector is in the same situation. Banking institutions are giving more work pressure to their employees. But it is very obvious, in order to being in the office for long time; employees become unable to spend much time with their families. So the employees cannot balance their professional life and personal life. And the term 'Work Life balance' is 
becoming a very important topic to understand in recent times for a developing country like Bangladesh. Employees are becoming much more concerned about both their personal life and professional life. Now-a-days employees need such type of job with which they are able to work efficiently and also can be able to maintain their families. If an employee fails to balance work life, work will become monotonous and will create pressure and trauma for himself. At the same time his family will face various worsened situations created by him. So, Work Life Balance (WLB) is very important in this regard too. Flexible working environment increases employees' job satisfaction and increases desire to be in the organization. Actually the more the organizations provide opportunities to their employees, the more they will have loyal and efficient employees. As a result, Work Life Balance has become one of the important issues of contemporary Human Resource Management. This report aims at exploring the present scenario of work life balance and its' relation with employee loyalty in the private commercial banking sector of Bangladesh.

The role of banking system in present economic developmental situation cannot be denied at all. Private Commercial Banking sector includes both conventional and Islamic shariah based commercial banks. There are 39 Private Commercial Banks in Bangladesh.

\subsection{Scope of the study:}

Importance of work life balance and employee loyalty is growing rapidly in banking industry due to the nature of the job. There are 39 private commercial banks in Bangladesh. This study is conducted on the employees of private commercial banks of Bangladesh.

\subsection{Statement of the problem:}

The ability to balance between workplace's needs and personal life's needs are considered as important factor to understand. Employees of private commercial banking sector of Bangladesh are selected to conduct the research. The traditional HR function doesn't provide extra ease for employees' personal lives. This in turn has impact on employees' job satisfaction as well as loyalty. In this era of competition it has become very much important for the managers to help employees to balance their personal and professional lives.

\section{Methodology of the Study}

\subsection{Sample selection:}

\subsubsection{Sample size:}

The population size is 39 private Commercial Banks of Bangladesh. Among them ten banks were selected randomly. The number of respondents is one hundred (100) from ten private commercial banks.

\subsection{Sampling Technique:}

The research is based on convenience sampling under the non-probability sampling technique. Samples are selected based on subjective judgment. Convenience sampling is used due to cost effectiveness and time constraint. 


\subsection{Sources of data:}

Data were collected from both primary and secondary sources. Primary data are collected through face to face interview and online questionnaire survey using Google doc using a structured questionnaire. As secondary sources various materials and documents from different websites related to the issue.

\subsection{Hypothesis to be tested: Hypothesis 1:}

$\boldsymbol{H}_{I}$ : Organization's leave policy and arrangements of holiday camps help to balance work life of employees.

\section{Hypothesis 2:}

$\boldsymbol{H}_{2}$ : Working environment and social factor help to balance work life of employees.

\section{Hypothesis 3:}

$\boldsymbol{H}_{3}$ : Work distribution among employees helps to balance work life.

\section{Hypothesis 4:}

$\boldsymbol{H}_{4}$ : Work Life Balance facilities increase loyalty of employees to the organization.

\subsection{Objective of the study:}

The main purpose of the study is to find out the impact of Work Life Balance and employee loyalty in the private commercial banks of Bangladesh. The specific objectives are given below:

$>$ To examine to what extend the private commercial banks are giving opportunities to their employees to have proper work life balance.

$>$ To explore the perceptions of the employees those are dependent on their Work Life Balance.

$>$ To identify the factors those are very important and related to have proper Work Life Balance.

$>$ To identify whether the employees and employers are able to maintain quality of work life in the current work schedule.

\section{Literature Review}

The term Work Life Balance is still a very new concept in the private commercial banking sector in Bangladesh. But it is taking important area of focus rapidly. Clarke, Koch and Hill (2004, p.121) said that WLB is an equipoise or the process of conserving the concordance in life. Work life balance is not something that just happens. It involves the efforts of a number of partners: the employee, the organization for which the employee works, the family with whom the employee lives and the society in which all are embedded. It involves mutual understanding and respect between all of these players. (N.Gayathri\&Dr.P. Karthikeyan, August 2013).

RebbeccaBundhun quotes in an Abu Dhabhi National Paper; namely 'The National' that- men and women have a different perception about "life" part of the balance. Generally women try to give more time to their family, while men spend more time focusing on the development of their own career. She also quoted the paper of DrKattyMarmenout, a research fellow at the INSEAD School in Abu Dhabhi with his words that- work-life balance involves a proper balance and harmony on individual's priorities. As per researcher Murphy and Doherty (2011) there are various circumstances that affect employees' personal life and professional life. So, it is quite difficult to measure the actual factors that affect WLB. And to have a balanced life there should be a distinguishing line 
Journal of Economics and Sustainable Development ISSN 2222-1700 (Paper) ISSN 2222-2855 (Online)

between employees' home and work lives. Therefore, employees should know their family roles and work roles (Harvard Business Review, page 184).

Some researcher have identified the Masculinity-Femininity dimension which also can affect motivation (Bansal and Sharma 2012) whereas to increase sense of entitlement fathers tend to use work-life balance measures to spend time with the families (Gregory and Milner, 2011). Different researchers have referred Job satisfaction in different way. Borah (2012) referred it to as positive emotional feeling of an employee whereas Gupta and Sethi referred that- job satisfaction may be termed as a positive reaction of an individual towards job (Gupta A., and Sethi J.A., 2012, p.58). However, as revealed by Balasubramanian L. in her article sometimes a person finds that there are some valid reasons which trigger the decision to quit a job, especially if there is no satisfaction toward job as there are lack of desires and demands of personal life. Studies indicate that mismatch between managers and employees thinking increases employee turnover (Dawley, Andrews \&Bucklew, 2010). Employees can't enjoy their job if they used to work under inept and uncompromising manager (Muhammad Sajjad et. al, 2013).

Work-life balance policies can enhance productivity, reduce cost by improving staff retention rates, decrease negative spill-over's, reduce extended hours and fatigue to reduce negative effect on productivity which further minimizes stress and contribute to a safer and healthier workplace (Ratzo N. et al., 2011).

Employee Commitment has three levels. If an employee falls within the affective commitment level, they identify with and are emotionally attached to their organization so much so that they remain with the same employer because they want to (Pepe, 2010). If an employee falls within the continuance commitment level, they remain with the same employer for numerous years because they are aware of the expenses connected with leaving, so they choose to remain not because they want to, but because they need to (Pepe, 2010). Finally, if an employee exhibits normative commitment, they opt to stay with an organization, not because they want to, or because they have to but it's alternatively because they feel they ought to (Meyer \& Allen, 1991 as cited in Pepe, 2010).

Previous research proved that the flexible working hours contributed to higher job satisfaction, motivation and employee engagement (McNall et al., 2010). Therefore, to increase the employee motivation towards the vision and mission, each organization needs to emphasize on their staff welfare. Employees learn different kinds of behavior from workplace life and private life. Since reciprocal interactions between both the life domains occur a Green Work Life Balance Concept is suggested to facilitate environmentally friendly behavior for them. (N.Gayathri, Dr.P.Karthikeyan, (2013).

In essence, the term Work Life Balance has attracted enormous research exposure in the West, Work Life balance of individuals in Nigeria has got far less attention to explore (Ojo, 2014). G.Shiva (2013) explained the working women having small children are forced to leave their child in daycare or in hands of maid. This creates more tension for them and less concentrate on their work and also not able to give proper care for them at times. Nonetheless, there are quite a few research studies on work-family conflict in developing countries like India and Bangladesh and one of the reasons could be the lack of awareness of this issue as well as the lack of awareness of equal employment opportunity act. Ayesha Tabassum, TasnuvaRahman and KursiaJahan (2011) studied on the work life of employees of Private Commercial Banks in Bangladesh and found that there was lack of enterprise to identify difference between the male and female employees Work Life Balance facilities of the private commercial banks in Bangladesh. Actually here there is a lacking of employees' proper awareness toward this concept. 


\section{Findings and Analysis}

\subsection{Demographic Analysis:}

\subsubsection{Number of surveyed male and female employees:}

Figure 1 state that 100 employees were surveyed including male and female. Among them 75 employees are male and 25 employees are female. 46 male respondents are married which is 46\%, 28 male respondents are unmarried which is $28 \%$ and 1 male respondent is divorced which is $1 \%$.

\subsection{Factor Analysis:}

Factor analysis is used to identify underlying variables or factors that explain the pattern of correlation within a set of observation. Factor analysis is used for data reduction.

\subsubsection{KMO and Bartlett's Test:}

KMO stands for Kaiser-Meyer-Olkin test. Kaiser-Meyer-Olkin test of sampling adequacy examines the appropriateness of factor analysis. If value of KMO is less than .50 it implies that factor analysis may not be appropriate. If it is above .70, then the factor analysis will be excellent.

Table 1 discussed the value of KMO sampling adequacy, where the value is .698 which means that the sampling is adequate and factor analysis is appropriate for this study. It can be said that the sample size can explain $69.8 \%$ of the dependent variable that is Work Life Balance. This testing result is accepted as the significance level is .000, which means this variable set is statistically significant and the number of error is $\mathbf{0}$.

\subsubsection{Total Variance Explained:}

Table 2 explained the Eigen Value, rotation sums of squared loadings, and cumulative \%. 'Eigen Value' represents the total variance explained by each factor. Those variables that obtained Eigen values is more than 1 are elected to form factors and according to their nature three major factors are selected.

In the 'Rotation Sums of Squared Loadings' column, the Eigen values of the factors are displayed on the basis of rotation analysis. In case of component 1 Eigen value after rotation is '2.990'.

$\%$ of variance $=(2.990 / 11) 100=\mathbf{2 7 . 1 7 9 \%}$

By 'Cumulative \%' column it can be assured that $\mathbf{5 5 . 9 0 7 \%}$ of dependent variable (Work Life Balance) can be explained by these three factors.

\subsubsection{Rotated Component Matrix:}

Table 3 discussed the 'Rotated Component Matrix' which shows each variable's position under each factor using factor loading. Three components are extracted previously. Variables are clustered according to their nature and relationship in each component. In each component those variables are being clustered where the value of each variable is ' .50 ' or more than ' .50 '.

Name of these three components are given below:

\section{Leave policy and holiday camps:}

Leave policy and holiday camps are very important for employees' Work Life Balance'. Under this factor the variables are- time for family engagements, arrangements of holiday camps and picnics, ability to balance work life, WLB initiatives by the organization, leave policy of the organization, and medical facilities. 
Journal of Economics and Sustainable Development ISSN 2222-1700 (Paper) ISSN 2222-2855 (Online)

Vol.10, No.14, 2019

Working environment and Social factor:

Under this factor variables are- more pressure of work, family support, and positive attitude of colleagues.

Work distribution:

This factor consists of maternity leave and work distribution. Maternity leaves are very helpful for female employees of the organization.

\subsection{Regression Analysis of Work Life Balance and its' factors:}

Regression analysis is the process of developing statistical model where two types of variables are usedindependent variable and dependent variable. A simple regression line is given below:

$\mathrm{Y}=\mathrm{a}+\mathrm{bX}$

Here, ' $a$ ' is the intercept which represents the constant value that means the value of $Y$ when $X=0$.

' $b$ ' is the slope which represents the expected change in the $\mathrm{Y}$ (dependent variable) for the change of 1 unit of $\mathrm{X}$.

\subsubsection{Model Summary:}

Table 4 states 'Model Summary' table. This table provides the value of ' $R$ ' and ' $R$ square'.

In case of multiple regressions ' $\mathbf{R}$ ' denotes the relationship between dependent variable and linear combination of independent variables. Here, the value of ' $R$ ' is $\mathbf{2 9 1}$ which represents weak relationship. That means relationship between Work Life Balance and its' variables is very weak.

'R Square' measures the proportion of variation in dependent variable that can be attributed to the independent variable. It reveals the variability due to the independent variable. In this case only $8.5 \%$ variability of WLB can be explained by the dependent variables that are leave policy and holiday camps; working environment and social factor, and work distribution.

'Adjusted R Square' is used when some independent variables do not add any new information to regression line but increase the value of R Square which causes inflated value of R Square. Here the value is only $\mathbf{5 . 6 \%}$ that means only $\mathbf{5 . 6 \%}$ variability of WLB can be explained by the dependent variables.

The deviation of data around the regression line is called 'Standard Error of the Estimates'. The value of standard error of estimate is $\mathbf{. 4 6 0}$.

\subsubsection{ANOVA:}

Table 5 analyzes the 'ANOVA' which shows how well the regression equation fits the data (i.e., predicts the dependent variable). This table indicates that the regression model predicts the dependent variable significantly well. The value of significance is $\mathbf{. 0 3 6}$ less than $\mathbf{. 0 5}$, which means $\mathbf{3 . 6 \%}$ errors occurred. And it is statistically significant.

'Sum of Squares' describes the variation which is attributed to the relationship between dependent and independent variable which shows the explained variation values. Here sum of squares is $\mathbf{1 . 8 7 4}$.

'df' shows the number of independent variable. Here degree of freedom of regression is $\mathbf{3}$. In case of residual $\mathrm{df}=$ $\mathrm{N}-\mathrm{K}-1=100-3-1=96$. So the number of independent variable is 99.

'Mean Square' means average deviation of degree of freedom of regression. It is the ratio between sum of squares and df. Here, 
$=1.874 / 3=.625$

Mean square $($ Residual $)=$ Sum of squares $/ \mathrm{df}$

$$
=20.285 / 96=.211
$$

'F Test' is the ratio between Mean Square Regression and Mean Square Residual.

$$
\begin{gathered}
\mathrm{F}=\text { Mean Square Regression/ Mean Square Residual } \\
=.625 / .211=2.957
\end{gathered}
$$

\subsubsection{Coefficients:}

In table 6 it can be seen that leave policy and holiday camps; and work distribution have significance value .533 and .912. It means that in 1000 trial 533 and 912 time it is wrong. So, in drawing the regression line these two factors will not be used. Only in the factor working environment and social factor the value of significance is .004 . Here, error .4\% and it is included in the regression line. Standardized Coefficients mainly denotes the correlation. Work Life Balance is positively correlated with working environment and social factor and the value is .284. On the other hand WLB is negatively correlated with leave policy and holiday camps \& work distribution.

\subsubsection{Regression Line:}

The Regression line is:

$\mathbf{Y}=\mathbf{b}_{0}+\mathbf{b}_{1} \mathbf{X}_{1}+\mathbf{b}_{2} \mathbf{X}_{2}+\mathbf{b}_{3} \mathbf{X}_{3}$

After extraction of the insignificant factors the final regression line is-

$\mathbf{Y}=\mathbf{b}_{\mathbf{0}}+\mathbf{b}_{2} \mathbf{X}_{2}$

$=4.720+.134$ (Working environment and social factor).

Here,

$\mathrm{Y}=$ Work Life Balance.

$\mathrm{X}_{1}=$ Leave policy and holiday camps.

$\mathrm{X}_{2}=$ Working environment and social factor.

$\mathrm{X}_{3}=$ Work distribution.

This regression shows the impact of such influencing factors on dependent variable. It shows the change in Work Life Balance occurs by the change of working environment and social factors.

\subsection{Regression Analysis of Employee Loyalty and Work Life Balance:}

\subsubsection{Coefficients:}

In table 7 the value of significance is .000 that means no error occurred and it will be included in the regression line. The dependent variable is employee loyalty to the organization.

\subsubsection{Regression Line:}

The Regression line is:

$\mathbf{Y}=\mathbf{b}_{0}+\mathbf{b}_{1} \mathbf{X}_{1}$

Employee loy alty to the organization $=2.912+.404$ (Work Life Balance opportunities).

Here, 
$\mathrm{Y}=$ Employee loyalty to the organization.

$\mathrm{X}_{1}=$ Work Life Balance opportunities.

This regression shows the impact of such influencing factors on dependent variable. It shows the degree of change in employee loyalty occurs resulted by the change of Work Life Balance opportunities.

\subsection{Hypothesis testing:}

Table 8 discussed about the hypothesis and the test results of hypothesis.

\subsubsection{Hypothesis 1:}

In case of hypothesis $1, \mathrm{P}$ value is .533 which is very high and greater than .05 . It means that here there is error and the number of error is $53.3 \%$. So, it is not statistically significant and the null hypothesis is not rejected. And it can be said that organization's leave policy and arrangements of holiday camps do not help to balance work life of employees.

\subsubsection{Hypothesis 2:}

The null hypothesis is rejected. And the alternative hypothesis is accepted. It can be said that working environment and social factor help to balance work life of employees.

\subsubsection{Hypothesis 3:}

The null hypothesis is not rejected. And it can be said that work distribution among employees does not help to balance employees' work life.

\subsubsection{Hypothesis 4:}

As the alternative hypothesis is accepted, it can be said that work life balance facilities increase employee loyalty to the organization.

\subsection{Findings:}

Work Life Balance is one of the major issues of consideration for employees' mental health and work output. It also helps to increase the percentage of employee retention and employees become more loyal to their organization. Based on the data analysis part major findings are identified and given below:

$>$ Most of the respondents surveyed, said that their organizations are providing them with some Work Life Balance facilities. That means some private commercial banks surveyed provide their employees with some WLB facilities. But some banks are not providing such facilities.

$>$ Most of the respondents said that they have more pressure of work in the current workplace. More pressure of work makes employees' life monotonous and employees become frustrated. It is a great hindrance toward employee loyalty.

$>$ A number of respondents said that they don't get enough time for their family. That means some banks' working hours are not proper and employees have to stay in their workplace for a long time.

$>$ Maternity leave is strictly followed in every banks surveyed. This is a good sign indeed.

$>$ About $40 \%$ respondents said that their organizations don't arrange holiday camps and picnics for them. So it also differs from banks to banks. 
$>$ On the basis of the respondents feedback it can be said that some banks don't provide their employees with proper medical facilities.

$>$ Some respondents are moderately satisfied with their leave policy.

$>$ Most of the respondents agree that they have friendly superiors and colleagues who are more helpful and cooperative which may be one of the reasons for job satisfaction.

$>$ The variables that are used as Work Life Balance facilities are statistically significant because significance level is 0.00 .

$>$ From factor analysis three factors are extracted and these three factors can explain almost $55.907 \%$ of the dependent variable that is Work Life Balance.

$>$ So, the three factors are-leave policy and holiday camps; working environment and social factor; and work distribution.

$>$ From the three factors a regression line has been drawn to show the dependency of Work Life Balance on these factors provided by the organization.

$>$ It is seen that degree of employees' Work Life balance changes with change of working environment and social factors such as pressure of work, family support, positive attitude of colleagues, and job satisfaction.

$>$ Lastly, a regression line has been drawn which is showing that employee loyalty is dependent on Work Life Balance opportunities provided by the organization.

\section{Conclusion}

The term Work Life Balance is one of the contemporary ideas that make organizations more productive. And WLB has a close relationship with employee loyalty. It is known that Private Commercial Banking organizations of Bangladesh are providing their employees with lucrative salaries and benefits. But they are providing more pressure of work. So, Work Life Balance has become a very important issue of consideration for employees. And it has great impact on employee loyalty. From various analyses here, it is seen that working environment and social factors like family support, positive attitude of colleagues, less pressure of work etc. are very important for employees to balance their work and family life. It impacts on employee loyalty. So the managing committee of private commercial banking organizations of Bangladesh should take various steps regarding work life balance. If the organization provides proper Work Life balance facilities to their employees, employees will be motivated to work. This in turn will increase organization's productivity.

\section{Recommendations:}

The employees in private commercial banks of Bangladesh are taking part in the economic growth by contributing their knowledge, skills and efforts. To get proper output from them, Work Life Balance opportunities are must. This is not a concept for female employees only rather this is a concept of both male and female employees as they both have to maintain their own families. Although most of the respondents agreed with banks' WLB policies but they disagreed with overall WLB opportunities. So the employees should be given the facilities like flexible time; job sharing; leave policy crèche facilities for women employees and necessary breaks so that they feel that the organization is helping them in coordinating the family and professional life. The management should take steps toward improving the morale of the employees by implementing organizational strategies that would enhance the 
work culture. Various workshops for motivating employees should be arranged which can help to minimize dissatisfaction. More job security should be provided to the employees. Certain modern techniques like Yoga, Instrumental activities should be included in organization to reduce the job stress. There must be brain storming between employees and employers relating to their job profile, job stress, and salary from time to time in order to increase their job commitment. Most of the respondents are eager to have flexible working hours. Flexible working hours should be ensured as it is a core source of employees' mental satisfaction. Employees should be provided with a fixed eight hours of working. Management should make some policy so that employees' working hours should not be more than eight hours a day. Every private commercial bank should have transportation facilities. Transportation facilities help employees to reach the workplace timely. Also it will help employees to reach their home timely. Organization should hire more employees so that employees' work pressure can be reduced as they need to compete with various emerging companies. Employees will work more enthusiastically if they can have the opportunity to choose their preferred area of work. This choice of relocation is very fruitful through which a large number of employees will be benefited as they will be able to be with their family members. Work should be distributed equally to improve the satisfaction of employees. Banks should introduce some kind of job sharing options in which work is distributed properly which can save extra time. It will improve the employee's commitment and satisfaction level along with productivity and profitability. Positive and friendly attitude of colleagues is very important to create a good working environment. The manager should act and maintain a friendly relationship with employees. Through this employees will feel happy in working and their families will get positive behavior from them. The Managing Committee of the Private Commercial banks of Bangladesh should be more aware of their employees' mental satisfaction and physical health.

\section{References}

Balasubramanian, L. (2013). When You Should Quit Your Job? The times of India, Ahmedabad

Clarke, M. C., Koch, L. C. \& Hill, E. J. (2004) 'The work and family interface: Differentiating balance and fit'. Family and Consumer Sciences Research Journal, 33 (2): 121-140.

Dawley, D. D., Andrews, M.C. \&Bucklew, N. S.(2010). Enhancing the ties that bind: Mentoring as a moderator. Career Development International, 15, $259-278$.

Gayathri N, Karthikeyan P. A Review on Green Human Resource Management with Exclusive Allusion to Green Work Life Balance. International Research Journal of Business and Management 2013; 5: 40-45.

Gayathri N, Karthikeyan P. Work life balance in India-A social responsibility or a competitive tool.

International Research Journal of Business and Management 2013; 1: 103-109.

Gupta, A., and Sethi, J.A., (2012). Impact of Quality of Work Life on Employees Perceived Performance, Job Satisfaction and Employee Commitment. Global Journal of Management and Research, Issue: Oct-Dec 2012, pp.56-70

Kumari KT, Devi VR. Impact of Demographic Variables on Work Life Balance of Women Employees (with special reference to Bangalore City). International Journal of Advances in Management and Economics 2012; 1(6): 226-229.

Mani V. Work Life Balance and Women Professionals. Global Journal of Management and Business Research Interdisciplinary 2013; 13(5): 2013

McNall, L. A., Masuda, A. D., \&Nicklin, J. M. (2010). Flexible Work Arrangements, Job Satisfaction, and Turnover Intentions: The Mediating Role of Work-to-Family Enrichment. The Journal of Psychology, 144(1), 61-81.

Murphy, F. \& Doherty, L.(2011). The experience of work life balance for Irish senior Managers.

Equality, Diversity and Inclusion: An International Journal, Vol.30 Iss:4, pp.252-277, Emerald Group Publishing Limited.

Pepe, M. (2010). The impact of extrinsic motivational dissatisfies on employee level of job satisfaction and commitment resulting in the intent to turnover. Journal of Business \& Economics Research, 8(9), 99-107.

Ratzon,N., Schejter, T., Alon, E., \&Schreuer, N. (2011). Are young adults with special needs ready for the physical work demands? Research in Developmental Disabilities, 32, 371-376, ELSEVIER. 
Rebecca Bundhun (2009). Checking the work-life balance. Retrieved from: http://www.thenational.ae/business/checking-thework-life-balance, accessed on 28.010.2016

Santhana Lakshmi K, SujathaGopinath S. Work Life Balance of Women Employees with reference to teaching faculties. International Monthly Refereed Journal of Research in Management and Technology 2013;II.

Tabassum A., Rahman T., Jahan K. (2011). "Quality of Work Life among Male and Female Employees of Private Commercial Banks in Bangladesh", Int. Journal of Economics and Management, Vol.5 (1), pp: 266-282.

\begin{tabular}{|c|c|c|c|c|c|}
\hline \multicolumn{6}{|c|}{ Gender } \\
\hline & & Frequency & Percent & Valid Percent & $\begin{array}{c}\text { Cumulative } \\
\text { Percent }\end{array}$ \\
\hline \multirow[t]{3}{*}{ Valid } & Male & 75 & 75.0 & 75.0 & 75.0 \\
\hline & Female & 25 & 25.0 & 25.0 & 100.0 \\
\hline & Total & 100 & 100.0 & 100.0 & \\
\hline
\end{tabular}

Source: Field survey, 2016

Figure 1: Percentage of male and female employees surveyed

KMO and Bartlett's Test

\begin{tabular}{|c|c|c|}
\hline \multicolumn{2}{|c|}{ Kaiser-Meyer-Olkin Measure of Sampling Adequacy. } & .698 \\
\hline Bartlett's Test of Sphericity & Approx. Chi-Square & 256.953 \\
\hline & Df & 55 \\
\hline & Sig. & .000 \\
\hline
\end{tabular}

Source: Field survey, 2016

Table 1: KMO and Bartlett's test

Total Variance Explained

\begin{tabular}{|l|r|r|r|r|r|r|}
\hline \multirow{2}{*}{$\begin{array}{l}\text { Compo } \\
\text { nent }\end{array}$} & \multicolumn{3}{|c|}{ Initial Eigenvalues } & \multicolumn{2}{|c|}{ Rotation Sums of Squared Loadings } \\
\cline { 2 - 7 } 1 & Total & \% of Variance & Cumulative \% & Total & \% of Variance & Cumulative \% \\
\hline 2 & 3.192 & 29.015 & 29.015 & 2.990 & 27.179 & 27.179 \\
3 & 1.731 & 15.741 & 44.756 & 1.881 & 17.104 & 44.284 \\
4 & 1.227 & 11.151 & 55.907 & 1.279 & 11.623 & 55.907 \\
5 & .976 & 8.870 & 64.777 & & & \\
6 & .853 & 7.750 & 72.528 & & & \\
7 & .731 & 6.643 & 79.171 & & & \\
8 & .644 & 5.851 & 85.022 & & & \\
9 & .530 & 4.815 & 89.836 & & & \\
10 & .492 & 4.474 & 94.311 & & & \\
11 & .263 & 3.302 & 97.613 & & & \\
\end{tabular}

Extraction Method: Principal Component Analysis.

Source: Field survey, 2016

Table 2: Total Variance Explained 
Rotated Component Matrix ${ }^{\mathrm{a}}$

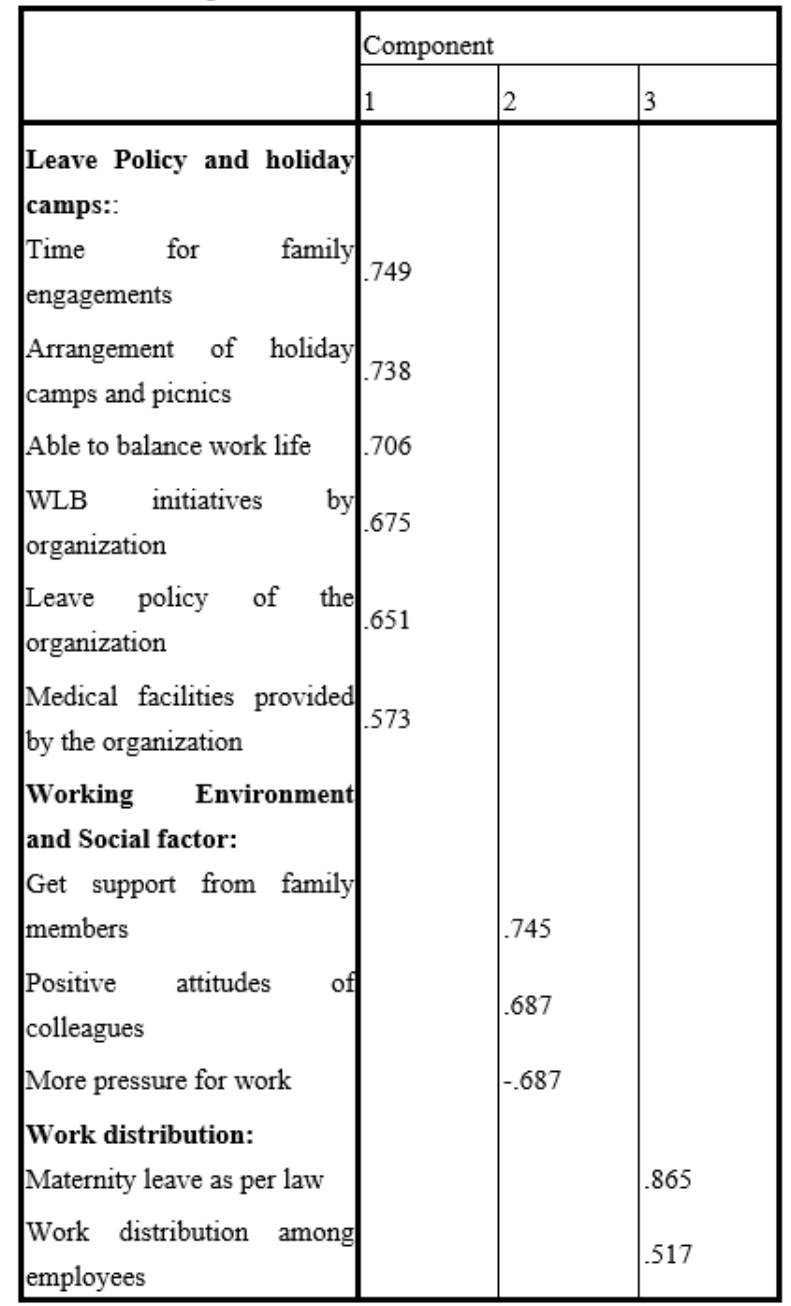

Extraction Method: Principal Component Analysis.

Rotation Method: Varimax with Kaiser Normalization.

a. Rotation converged in 5 iterations.

Source: Field survey, 2016

Table 3: Rotated Component Matrix 


\section{Model Summary}

\begin{tabular}{|l|r|r|r|r|}
\hline Model & \multicolumn{1}{|c|}{$\mathrm{R}$} & R Square & \multicolumn{1}{c|}{$\begin{array}{c}\text { Adjusted R } \\
\text { Square }\end{array}$} & $\begin{array}{c}\text { Std. Error of the } \\
\text { Estimate }\end{array}$ \\
\hline 1 & $.291^{\mathrm{a}}$ & .085 & .056 & .460 \\
\hline
\end{tabular}

a. Predictors: (Constant), Work distribution, Working environment and social factor, Leave policy and holiday camps

Source: Field survey, 2016

Table 4: Model Summary

ANOVA $^{b}$

\begin{tabular}{|rr|r|r|r|r|r|}
\hline Model & & Sum of Squares & Df & Mean Square & F & Sig. \\
\hline 1 & Regression & 1.874 & 3 & .625 & 2.957 & $.036^{\mathrm{a}}$ \\
& Residual & 20.286 & 96 & .211 & & \\
& 22.160 & 99 & & & \\
\hline
\end{tabular}

a. Predictors: (Constant), Work distribution, Working environment and social factor, Leave policy and holiday camps

b. Dependent Variable: In current situation WLB is very much important Source: Field survey, 2016

Table 5: ANOVA

\section{Coefficients $^{\mathrm{a}}$}

\begin{tabular}{|c|c|c|c|c|c|c|}
\hline \multirow{2}{*}{\multicolumn{2}{|c|}{ Model }} & \multicolumn{2}{|c|}{ Unstandardized Coefficients } & \multirow{2}{*}{$\begin{array}{l}\text { Standardized } \\
\text { Coefficients } \\
\text { Beta }\end{array}$} & \multirow[b]{2}{*}{$\mathrm{T}$} & \multirow[b]{2}{*}{ Sig. } \\
\hline & & B & Std. Error & & & \\
\hline \multirow[t]{4}{*}{1} & (Constant) & 4.720 & .046 & & 102.679 & .000 \\
\hline & $\begin{array}{l}\text { Leave policy and holiday } \\
\text { camps }\end{array}$ & -.029 & .046 & -.061 & -.625 & .533 \\
\hline & $\begin{array}{l}\text { Working environment and } \\
\text { social factor }\end{array}$ & .134 & .046 & .284 & 2.910 & .004 \\
\hline & Work distribution & -.005 & .046 & -.011 & -.111 & .912 \\
\hline
\end{tabular}

a. Dependent Variable: In current situation WLB is very much important

Source: Field survey, 2016

Table 6: Coefficients 


IISt:

\section{Coefficients}

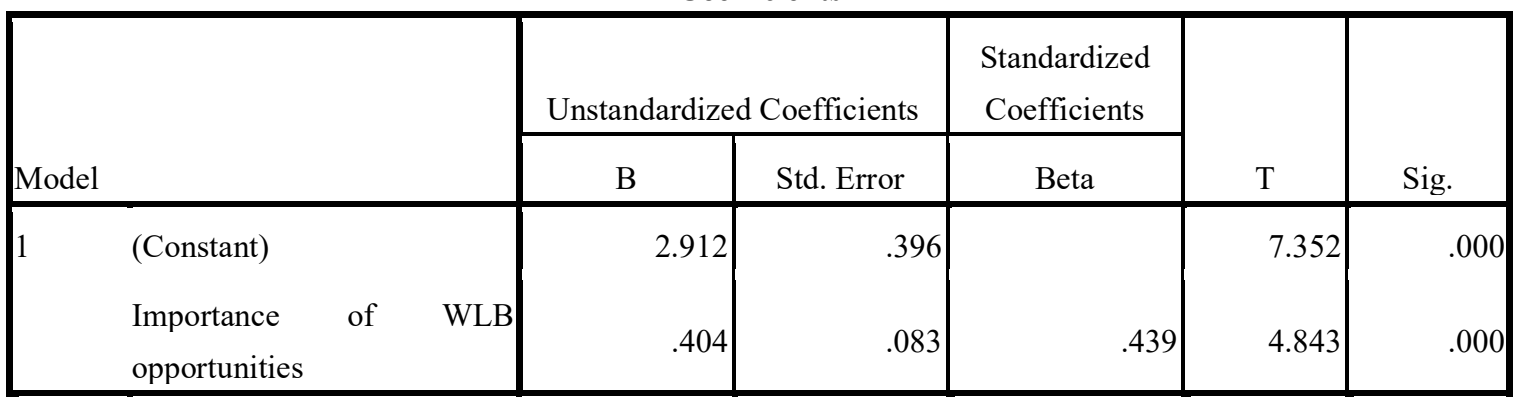

a. Dependent Variable: Employee loyalty to the organization

Source: Field survey, 2016

\section{Table 7: Coefficients}

\begin{tabular}{|c|l|c|c|c|}
\hline Hypothesis & \multicolumn{1}{|c|}{$\begin{array}{c}\text { Null Hypothesis } \\
\left(\mathbf{H}_{\mathbf{0}}\right)\end{array}$} & \multicolumn{1}{|c|}{ 't' Value } & $\begin{array}{c}\text { Sig. level } \\
\text { (P value) }\end{array}$ & Remarks \\
\hline 1. & $\begin{array}{l}\text { Organization's leave policy and arrangements of } \\
\text { holiday camps do not help to balance work life of } \\
\text { employees. }\end{array}$ & -.625 & .533 & Not Rejected \\
\hline 2. & $\begin{array}{l}\text { Working environment and social factor do not } \\
\text { help to balance work life of employees. }\end{array}$ & 2.910 & .004 & Rejected \\
\hline 3. & $\begin{array}{l}\text { Work distribution among employees does not help } \\
\text { to balance work life. }\end{array}$ & -.111 & .912 & .000 \\
\hline 4. & $\begin{array}{l}\text { Work Life Balance facilities do not increase } \\
\text { loyalty of employees to the organization. }\end{array}$ & 4.843 & & Rejected \\
\hline
\end{tabular}

Source: Field survey, 2016

Table 8: Test result of hypothesis 